2. Засєда Л. Верхнє світло: краєвид 3 вікна. https://day.kyiv.ua/ uk/blog/suspilstvo/verhnye-svitlo-krayevyd-z-vikna

3. СБУ затримала трьох організаторів псевдо референдуму на Донбасі. I серед них «міністр ДНР» // Вечірня Полтава. 2015. - https: // ssu. gov. ua / photo-galleries / sbu-zatrymala-orhanizatoriv-trokh-uhrupovanyaki-zaimalys-perepravlenniam-nelehaliv-cherez-derzhavnyi-kordon

4. Стишов О. А. Динамічні процеси в лексико-семантичній системі та в словотворі української мови кінця XX ст. (на матеріалі мови засобів масової інформації): автореф. дис..... доктора філологічних наук. Київ: Київський національний лінгвістичний університет, 2003. 33 с.

5. У Миколаєві отруїлося 17 людей! I 3-поміж них - 5 дітей! galinfo. 2013. https://galinfo.com.ua/news/u_mykolaievi_17_lyudey_ otruilysya_u_kafe_133861. Html

DOI https://doi.org/10.30525/978-9934-26-073-5-2-45

\title{
MEANS OF VERBAL INFLUENCE IN BRITISH AND AMERICAN WEB-BASED MEDIA
}

\author{
Revenko V. V. \\ Candidate of Pedagogical Sciences, \\ Senior Lecturer at the English Philology Department \\ Kryvyi Rih State Pedagogical University \\ Khoroshylova N. S. \\ Student at the Faculty of Foreign Languages \\ Kryvyi Rih State Pedagogical University \\ Kryvyi Rih, Dnipropetrovsk region, Ukraine
}

The XXI century is accompanied by significant development of mass media and the increasing number of academic studies on various aspects of language functioning in the media. The research of various aspects of the functioning of the language of the media, namely the typology of media texts, their stylistic features, the peculiarities of journalistic style, psychology of mass communication is carried out by Ukrainian (O. Andreichenko, M. Zhovtobriukh， T. Kots， L. Kuziv， H. Shapovalova etc.) and foreign (A. Bell, T. van Dijk, T. Dobrosklonskaya, M. Montgomery, S. Smetanina, G. Solganik, R. Fowler and others) scientists. 
The function of modern media is not only limited to news reporting or event description. The considerable increase in the number of Internet publications causes increased demands for their informative value, visibility and efficiency, and influence on the target audience. Therefore, the issue of the use of means of realization of verbal influence in British and American political media texts remains particularly relevant nowadays.

The aim of our research is to study the means of verbal influence in modern British and American web-based political media texts.

The analysis of the investigations of T. Dobrosklonskaya [2], E. Glinchevsky[1], M. Muratova[3], I. Sternin[5] in regard to the ways of expressing verbal influence shows that they are represented at the level of the composition of media texts, and at lexico-semantic, morpho-syntactic and phonological levels. Regardless of their diversity they are used to demonstrate implicit positive/negative estimation, influence the reader at the emotional level, outline the necessary concept of current events, and convince of their credibility.

At the level of composition the structure of the headlines of media texts is one of the most wide-spread means of expressing verbal influence. The most common are narrative statements, in which the informative function is combined with the pragmatic one. They make it possible to realize such authorial intentions as statement, warning, explanation, prediction, assumption, irony, invitation to read the facts. Examples:

1) «SEE IT!: Whoopi Goldberg calls Trump a wannabe dictator and berates him for 'attempted coup'». In this example, by using an exclamation, the journalist focuses the readers' attention on the importance of this message.

Of particular interest are the headings with partial quotation. Example:

2) «Biden to say it's «time to end America's longest war» as he announces Afghanistan troop withdrawal».

The «question-answer» headings deserve special consideration. The first part of the heading consists of a simple question that does not reveal the main content of the article. And the second part in the form of a narrative sentence provides more detailed information in the form of an answer to the question. Example:

3) «Who won PMQs? Emily Thornberry is the real deal».

According to E.Glinchevsky [1, p.25], the use of lingvostylistic expressive means enhances verbal influence. They comprise such devices as metaphor, metonymy, comparison, allusion, epithet, expressive vocabulary with ideological connotations.

Our analysis of the coverage of the recent presidential election in the United States by British and American online media led to the conclusion that the use of words with political connotations is a powerful tool to influence the 
addressee, which allows him to form the necessary ideas about events, happening in the world. We have selected the words and phrases that are most used to describe current events:

the Democrat frontrunner, rigged election, racist comments, controversial candidacy, whites / nonwhite voters, racial disregard, Republican rival, largescale voter fraud, harassment of minorities [4, p. 63].

The use of metaphors is the most common means of implementing verbal influence, which allows the author to increase expressiveness and is used not only as a figurative means, but also as a means of evaluation. Example:

4) «Now, on a day that promised to be a new dawn in American politics but that looks increasingly like our racial dusk, it occurs to me that this young man came to me not only out of intellectual striving but existential worry».

Following T. Dobrosklonskaya [2], we consider the syntactic structure of sentences to be of great importance to express verbal influence, which presupposes the use of interrogative constructions, word order, the use of repetitions, adverbial clauses of condition. Examples:

5) «How can any black American securely exist in a country where his or her future is haunted by the past, making the present an almost-impossible-toembrace moment of both hope and fear? « (interrogative sentence);

6) «One tells us: «Libya is a failed state. Iraq is a failed state. Syria is a failed state. There is no government to keep a lid on the radical jihadists» (the use of repetitions).

Along with the other techniques that have been outlined above, they are primarily aimed at implementing the function of influencing the recipient and allow the author to implicitly assess the events discussed.

\section{References:}

1.Э.И. Глинчевский. Средства речевого воздействия в языке СМИ.Вестник МГУ. Сер. 19. Лингвистика и межкультурная коммуникащия. 2005. № 4. С. 18-27.

2. Добросклонская Т. Г. Язык политического медиадискурса Великобритании и США. Язык СМИ и политика. Москва, 2012. C. 741-784.

3. Муратова М. Средства речевого воздействия в языке СМИ. URL: http://old.russ.ru/politics/20030127-apelsin-pr.html

4. Ревенко.В.В. Засоби реалізації категорії ідеологічної модальності в сучасних британських та американських інтернет-виданнях . Держава та регіони. Серія : Гуманітарні науки : наук.-вироб. журн. 2017. № 2(49). C. 60-65.

5. Стернин И. А. Введение в речевое воздействие. Воронеж, 2001. $252 \mathrm{c}$. 